\title{
EFFECT OF LAMBING DATE ON PRODUCTTON FROM BREEDING EWES AND ON PASTURE ALLOWANCE AND INTAKE
}

\author{
P. V. RatTray \\ Ruakura Agricultural Centre, MAF, Hamilton
}

\begin{abstract}
In an attempt to improve the synchronization of the feed requirements of the breeding ewe with the onset of spring pasture growth, lambing was delayed one month (mean lambing date August 31 us. October 1) in a 3-year experiment with 5-year-old ewes stocked at two rates ( 21.3 vs. 27.7 ewes/ha). There was no effect of stocking rate or lambing date on annual pasture growth. However, the later lambing groups had higher available pre-grazing DM yields in late pregnancy and early lactation. This resuited in higher pasture allowances and pasture intakes in late pregnancy $(+0.6$ and + 0.3-0.5 kg DM/ewe/day) and in early lactation (+ 1.4 and + 0.3-0.9 $\mathrm{kg} \mathrm{DM/ewe/day),} \mathrm{respectively.} \mathrm{The} \mathrm{late} \mathrm{lambing} \mathrm{ewes}$ were $5 \mathrm{~kg}$ and $1.5-2.0 \mathrm{~kg}$ heavier pre-lambing and 4 weeks postlambing, while their lambs were $0.7-1.4 \mathrm{~kg}$ heavier at 4 weeks. Compared with the early groups the later lambing ewes lost more weight and their lambs had lower growth rates from weeks 4 to 10 of lactation, although pasture allowances and intakes were similar to the early groups during the same lactation period. The poorer performance of the later lambing groups ov-er this period appeared to be associated with a decline in pasture digestibility.
\end{abstract}

\section{INTRODUCTION}

In many situations conventional lambing dates result in a feed deficit, not met by pasture growth over the late winter-early spring period. If synchrony of the increasing feed requirements over late pregnancy and early lactation in breeding ewes and the onset of spring pasture growth could be improved. an increase in lamb growth might result. Furthermore, the need to conserve spring pasture surpluses for winter feeding, to make up feed requirement deficits, might also be reduced.

The effect of delaying mean lambing date by approximately one month on animal performance and on the allowance, intake, and quality of pasture was investigated at two stocking rates, over three years.

\section{Trial Design}

\section{EXPERIMENTAL}

During the three years 1973-5, five-year-old ewes were run on separate farmlets: Romneys i- 1973 and 1974 and Coopworths 
in 1975. Each farmlet contained 14 or 15 equal-sized paddocks and was stocked on a 12-month basis by 56 ewes. The stocking rates (ewes/ha) and average lambing dates were as follows: 21.3, August 30 (LE) ; 27.7, September 1 (HE) ; 21.3, October 2 (LL) ; and 27.7 October 1 (HL). Dorset Horn rams ran with the ewes for the equivalent of two oestrous cycles at each mating date. Paddocks of each farmlet were randomized over the following soil types: Hamilton clay loam, Rolokauri clay loam, Te Kowhai silt loam (peaty phase), Te Rapa peaty loam, and Te Rapa peaty sandy loam, and were topdressed with $150 \mathrm{~kg}$ of $15 \%$ potassic superphosphate each spring and autumn.

Animals were weighed and lambs were drenched at monthly intervals. All ewes which died were replaced immediately to maintain stocking rate and after lambing numbers of singles and twins were balanced between groups. Atter weaning any dead lambs were also replaced.

\section{Milk Production}

Milk production was estimated weekly from 10 twin-suckling ewes per treatment, using oxytocin injections (10 i.u. intrajugularly) and milking machines (Rattray ef al., 1975).

\section{GRAZING MANAGEMENT}

Rotational grazing was adopted except for approximately one month over lambing when ewes were set-stocked on two-thirds of each farmlet. From docking to weaning rotation length was 2 weeks. After weaning lambs received preferential treatment and ewes were used to clean up some pastures that had previously been grazed by the lambs. All lambs were slaughtered 6 weeks before mating. During flushing and mating rotation length was approximately 3 weeks. Rotation length was extended to 60 days during winter (after mating) until late pregnancy, when it was gradually reduced to 4 weeks. Hay was on offer to all groups when grazing appeared limiting.

\section{Pasture Measurements}

Group intakes and pasture growth were estimated by a pasture cutting technique similar to that of Campbell (1969), but with the use of exclosure cages. There were 5 sample paddocks per treatment and 4 sets of cuts were made at each estimation.

Weeklv samples of pre-grazing herbage were taken for in vitro digestibility determination. 


\section{RESULTS AND DISCUSSION}

Ewe and Lamb Liveweights, Fleece Weights anu Milk Production

Liveweights of the ewes and lambs are shown in Tabie 1. The ewes of the low-stocked and late lambing groups were heavier pre-lambing $(\mathrm{P}<\mathbf{0 . 0 1})$ and 4 weeks post-lambing $(\mathrm{P}<\mathbf{0 . 0 1})$ than the high-stocked and early lambing groups. At weaning the trend was reversed, with early lambing ewes being the heavier $(P<0.05)$. There was no difference due to lambing date on ewe liveweights pre-mating. Differences due to stocking rate were significant at all stages $(P<0.05)$.

TABLE 1: LIVEWEIGHTS (kg) OF EWES AND LAMBS AND EWE FLEECE WEIGHT (kg) (3-year average)

\begin{tabular}{|c|c|c|c|c|c|}
\hline Treatment & LE & HE & $L L$ & $H L$ & $( \pm \mathrm{SE})$ \\
\hline \multicolumn{6}{|l|}{ Ewes: } \\
\hline Pre-lambing & 65.9 & 60.3 & 69.7 & 64.0 & 1.1 \\
\hline Post-lambing (4 wk) & 60.8 & 54.1 & 62.7 & 55.5 & 0.9 \\
\hline Weaning $(10$ wk) & 58.9 & 53.4 & 54.8 & 52.3 & 1.1 \\
\hline Pre-mating & 61.1 & 55.9 & 59.7 & 57.4 & 1.2 \\
\hline Fleece weight & 4.1 & 3.9 & 3.9 & 3.1 & 0.2 \\
\hline \multicolumn{6}{|l|}{ Lambs: } \\
\hline Birth & 4.7 & 4.7 & 4.8 & 4.8 & 0.1 \\
\hline 4 weeks & 11.5 & 10.6 & 12.2 & 12.0 & 0.3 \\
\hline Weaning (10 wk) & 23.0 & 21.9 & 21.2 & 20.3 & 0.4 \\
\hline Slaughter (20 wk) & 28.6 & 29.5 & 29.6 & 27.8 & 0.9 \\
\hline
\end{tabular}

There were no treatment differences in fleece weight or birthweight. Lambing percentage averaged 120 over the 3 years.

At 4 weeks of age the late-born lambs were 0.7 to $1.4 \mathrm{~kg}$ heavier $(P<0.05)$ than the early-born lambs, while at weaning they were lighter $(P<0.01)$ by 1.6 to $1.8 \mathrm{~kg}$. Low-stocked lambs were heavier at weaning than high-stocked lambs $(P<0.05)$. There were date of lambing $\mathbf{x}$ stocking rate interactions at 4 weeks and at weaning because at both ages the difference between stocking rates was only significant at the early lambing date. All treatment differences had disappeared by slaughter (20 weeks).

Although not significant, the trends in ewe milk production were similar to the ewe and lamb body-weight changes. Daily milk production in early lactation averaged $2.3,1.9,2.5$, and 2.2 1/day ( $\mathrm{SE} \pm 0.2)$, and in late lactation 1.4, 1.3, 1.2, and $1.0 \mathrm{l}$ /day $(\mathrm{SE} \pm 0.2$ ) for the $\mathrm{LE}, \mathrm{HE}, \mathrm{LL}$, and $\mathrm{HL}$ ewes, respec- 
tively. Milk composition did not differ. The higher lamb growth of the late lambs up to 4 weeks could have been due to higher milk consumption, while their poorer performance in late lactation could have been due partly to lower milk consumption. In the first month lambs eat very little pasture, but their pasture intakes increase as lactation progresses (Joyce and Rattray, 1970) .

\section{PastuRE Growth, Yietds and Digestibility}

There were no significant differences in total annual pasture growth between treatments (3-year average $15530 \mathrm{~kg}$ bM/ha/ yr) (Fig. 1). However, there were some small differences due to stocking rate at some stages of the year. Low-stocked pastures produced more DM during August-October $(+420 \mathrm{~kg}$ DM/ha $\bar{P}<0$. 10) a n d less duriitg Februaray-May $(-780 \mathrm{~kg} \mathrm{DM} / \mathrm{ha}$, $P<0.10)$ than high-stocked pastures. This former difference may have been due to hard grazing of high-stocked pastures (Fig. 2) in the winter and spring. The high-stocked pastures may have been more vigorous in the autumn, but as the technique measures net production, which is lower than absolute production because of the considerable decay that can occur at this time (Campbell, 1966; Hunt, 1971), this is uncertain. There was no marked depression of annual production at high stocking rates as reported by Campbell ( 1969), in spite of the higher grazing pressures.

Changes in pasture yields (Fig. 2) lagged behind changes in pasture growth, building up when utilization was less than the

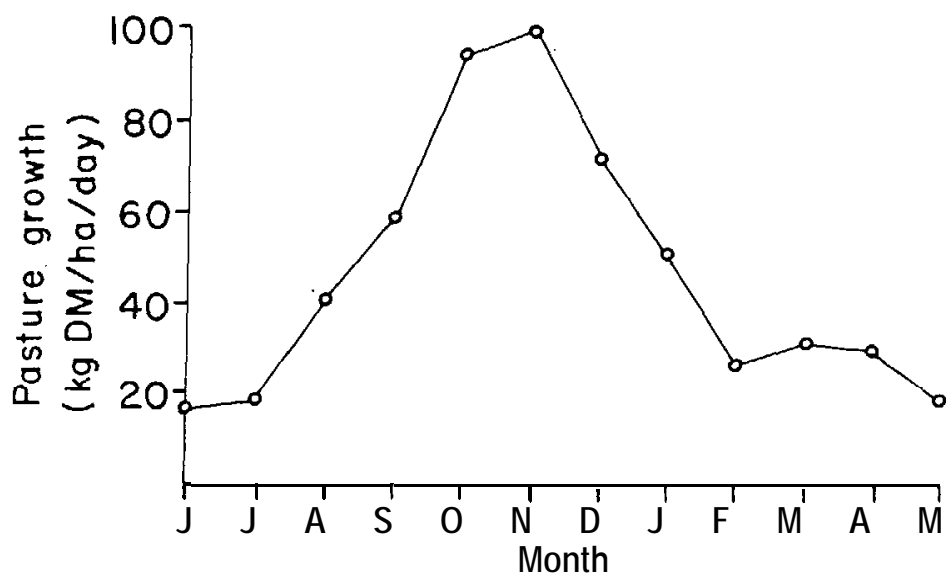

FIG. 1: Monthly pasture growth (3-year average). 


\section{LE QLL HE Q HL}

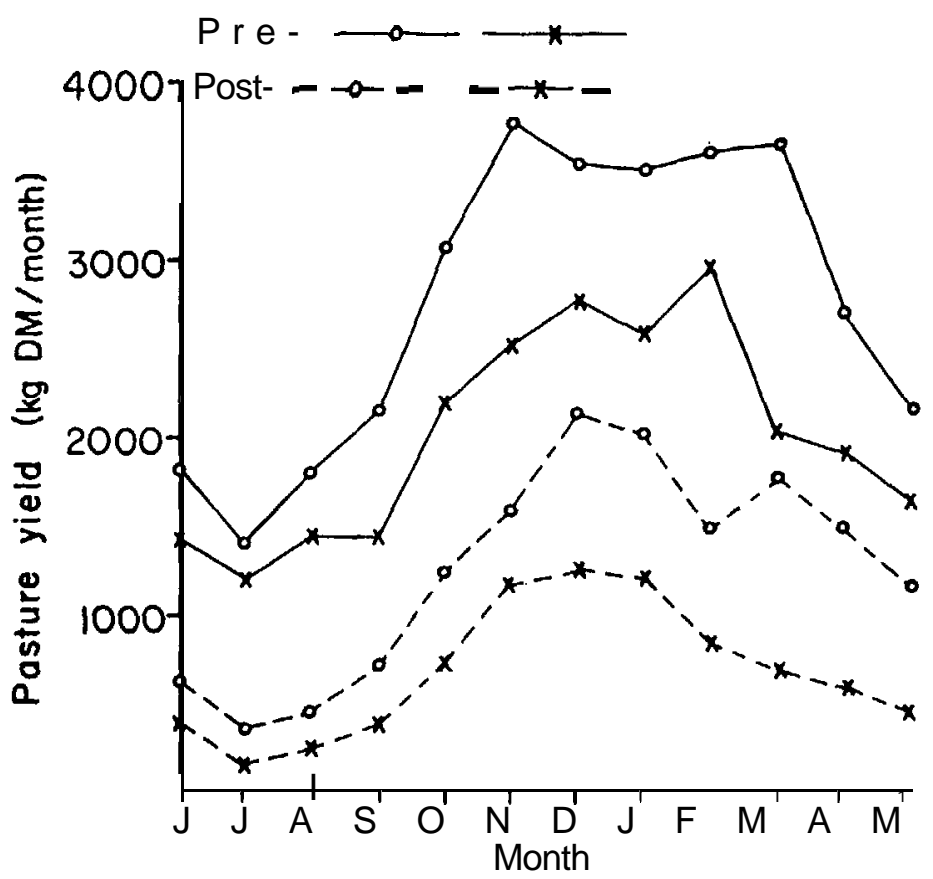

Frg. 2: Pre and post-grazing pasfure yieds (3-year average).

growth and falling when utilization or decay was greater than pasture growth. Pre- and post-grazing yields were higher for lowthan for high-stocked pastures $(P<0.01)$. Patterns were similar to those reported by Campbell (1969). Speed of rotation caused subtle differences to occur - e.g., shortening the rotation later in the spring for the late lambing groups led to greater yields in August and September than for the early lambing groups: however, differences due to lambing date during any one month were not significant. Later lambing groups had higher pasture yields during late pregnancy and early lactation than early groups, but not during mid- and late-lactation.

Seasonal in vitro OM digestibility changes (Fig. 3) were similar to in vivo trends found for sheep pastures at Whatawhata (J. P. Joyce, unpublished data). It must be emphasized that these in vitro digestibilities (Fig. 3) refer to that of the herbages on offer and not necessarily to that ingested during selective grazing. Differences in digestibility between treatments within months were small, but during November- January high-stocked 


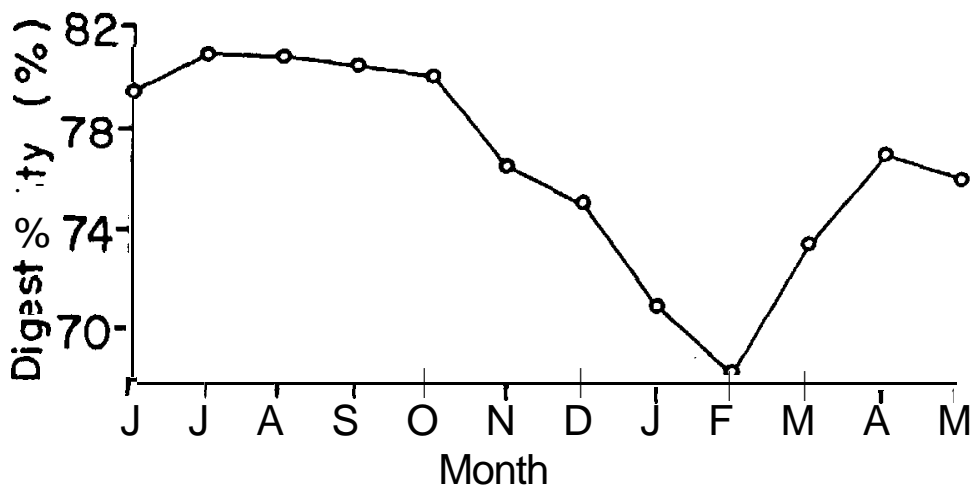

ت̈IG. 3: Monthly pasture in vitro digestibility (3-year average).

pastures were lower in digestibility than low-stocked pastures (by 1 to 3 units). This may have been due to sampling as these pastures were shorter and they appeared less mature than the higher yielding low-stocked pastures. The lower digestibility of the high-stocked pastures may have been due to higher amounts of less digestible stubble being included in these samples, compared with the low-stocked. After weaning ewes received only paddocks that had been grazed by the lambs. In vitro digestibility of this pre-grazing herbage for the ewes was 60 to $65 \%$ and was 10 percentage units lower than that received by lambs over the same period $(\mathrm{P}<0.001)$; this would be due to the lambs having previously selected more digestible components of the sward.

\section{Pasture Allowances and Pasture Intakes}

Table 2 shows the pattern of monthly pasture allowances throughout the year.

The effects of one-month delay in lambing in late groups and its influence on monthly allowances and intakes are well demonstrated. Compared with the low-stocked groups, the higher grazing pressures at the high-stocking rates throughout most of the year are also evident

The average pasture allowances and pasture intakes are summarized for the different physiological states of the ewe throughout the year in Table 3. The intakes are very similar to those found for ewes and lambs at the same pasture allowances by Rattray and Jagusch (1977) and Jagusch (unpublished data). After weaning there were no significant differences in allowance or intake owing to treatment because of the partial restriction on the ewes. Also during this period, because of their preferential 


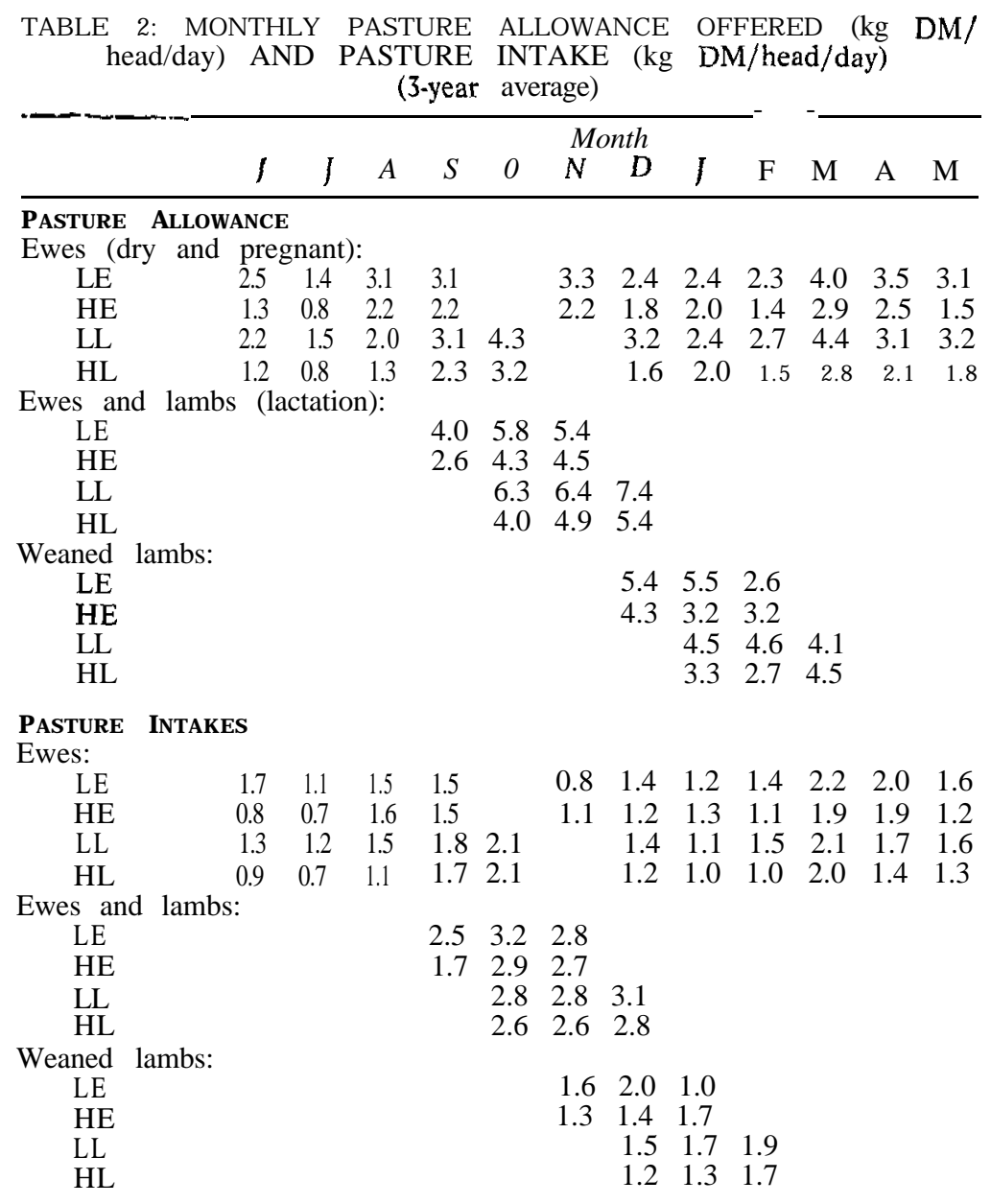

treatment there were no differences in allowances or intakes of the weaned lambs. In mid-pregnancy differences in both allowances and intake between stocking rates approached significance. During late pregnancy low-stocked and late groups had higher allowances than high-stocked and early groups $(\mathrm{P}<0.05)$. Intakes of the late groups were higher than those of the early groups $(P<0.05)$ but there were no differences between stocking rates. In early lactation both allowance and intake were significantly different between lambing dates $(P<0.05)$ and stocking rates $(\mathrm{P}<0.05)$, the $\mathrm{HE}$ group being markedly lower 
LAMBING DATE AND ANIMAL. PRODUCTION

TABLE 3: PASTURE OFFERED AND PASTURE INTAKE AT DIFFERENT PHYSIOLOGICAL STAGES (kg DM/head/day)

(3-year average)

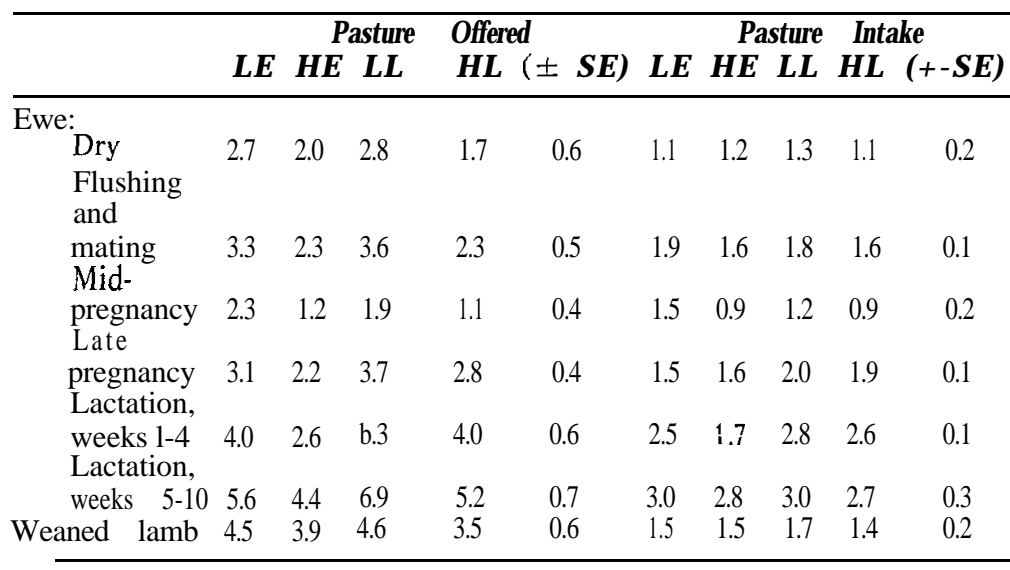

than the rest. Differences in allowances approached significance in late lactation, but intakes did not differ between treatments. Except during mid-late lactation, the liveweights of the ewes and lambs (Table 1) reflected the differences in allowances and intakes (Table 3).

Recent experiments (Rattray and Jagusch, 1977) would suggest that, in contrast to the late groups, the allowances and intakes of the early groups in late pregnancy and early lactation are less than optimum, especially for the high-stocked ewes. Although birth weights (Table 1) did not differ, this is not surprising as Rattray and Jagusch (1977) found no difference in birth weights of both singles and twins between groups offered 2.0 and $3.6 \mathrm{~kg}$ DM/ewe/day with intakes of 1.5 and $2.2 \mathrm{~kg} \mathrm{DM/ewe/day.} \mathrm{The}$ lower ewe and lamb gains (Table 1) and milk production of the late groups during the latter stages of lactation do not appear to be associated with a lowering of pasture allowance or intake (Table 3), but appear to be due to the seasonal decline in pasture digestibility (Fig. 3). This is somewhat surprising as the fall in digestibility was not great.

The hay intakes are shown in Table 4. As hay was on offer over the autumn, winter, and spring periods, these intakes partially reflect feed deficits not met by pasture. The high-stocked groups ate more than the low-stocked. Shortening the rotation for the early groups in late pregnancy (August) lowered the hay intakes of these groups, relative to the late groups, as a 
PROCEEDINGS N.Z. GRASSLAND ASSOCIATION

TABLE 4: HAY INTAKES ( $\mathrm{kg}$ DM/ewe/month) (3-year average)

\begin{tabular}{cccccccc}
\hline Month & $A$ & $M$ & $I$ & $I$ & $A$ & $S$ & $\begin{array}{c}\text { Total } \\
(\mathrm{kg} / \text { ewe })\end{array}$ \\
\hline LE & - & - & 0.2 & 1.3 & 0.7 & - & 2.2 \\
HE & $\mathbf{2 . 7}$ & 4.4 & 5.3 & 8.3 & 3.1 & 0.1 & 23.9 \\
LL & - & - & 0.1 & 0.9 & 1.2 & - & 2.2 \\
HL & 2.4 & 4.6 & 5.2 & 8.4 & 4.4 & 0.3 & 25.3 \\
\hline
\end{tabular}

greater proportion of their requirements was met by pasture. In comparison, the greater reduction in hay intakes of the late groups during late pregnancy (September) was a consequence of greater pasture growth and shortening the rotation. The increases that hay intake made to total daily intake were quite small in comparison with pasture intake (Table 3).

Total annual DM (pasture plus hay) intakes for the LE, HE, LL, and HL groups were 750, 675, 780, and $690 \mathrm{~kg} \mathrm{DM/ewe/}$ $\mathrm{yr}$, respectively. These estimates are close to those reported for a variety of breeds at different stocking rates (Joyce et al., 1976).

\section{CONCLUSIONS}

There was little total advantage in delaying lambing date by one month. Although it appeared to match feed requirements and pasture growth more closely in late pregnancy and early lactation (than lambing at conventional dates), the seasonal decline in pasture digestibility resulted in loss of this advantage in late lactation. Pasture management techniques (such as topping or silage-making) may help to arrest this decline in quality. Possibly the use of a highly digestible special-purpose crop such as lucerne or red clover for feeding in late lactation or as lamb feed after weaning would prevent this reduced performance. The early lambing ewes suffered a feed deficit in the spring (late pregnancy-early lactation) while the late lambing ewes suffered a feed quality decline in the summer (late lactation) and a feed deficit after weaning in drought years. These deficiencies were more noticeable at high stocking rates. Neither system resulted in the ideal synchrony.

\section{ACKNOWLEDGEMENTS}

The staff of the Nutrition Section, Ruakura Animal Research Station, for conducting various aspects of the trial. 


\section{REFERENCES}

Campbell, A. G., 1966. Proc. 10th int. Grassld Congr.: 458-63.

-. 1969. N.Z. Il agric. Res, 12: 67-74.

Hunt, W. F., 1971. N.Z. Il agric. Res., 14: $208-18$.

Joyce, I. P.; Clarke, I. N.; MacLean, K. S.; Cox, E. H., 1976. Proc. Rua. kura Fmrs' Conf.: 34-8.

Joyce, J. P.; Rattray, P. V., 1970. Proc. N.Z. Soc. Anim. Prod., 30: 94-105.

Rattray, P. V.; Jagusch, K. T., 1977. Proc. Ruakura Fmrs' Cont.: 49-51.

Rattray, P. V.; Morrison, M. C. L.; Oliver, T. W., 1975. Proc. N.Z. Soc. Anim. Prod., 35: 138-43. 